\title{
LED TUBS ARTIFICIAL LIGHTING SYSTEM IN BROILER PRODUCTION
}

\author{
Rogério Seber ${ }^{1 *}$, Daniella Moura², Nilsa Lima², Juliana Massari² \\ 1*Corresponding author. Universidade de Campinas/ Campinas - SP, Brasil. E-mail: rogerio.torres.seber@gmail.com
}

\section{KEYWORDS}

broiler, light, tubular light emitting diode.

\begin{abstract}
Light is important for the physiology and zootechnical development of broilers and is characterized by the type of source defined by the spectral emission and geometry of the lamp, as well as the intensity and spatial distribution of the illuminance. The aim of this study was to verify the influence of an artificial lighting system based on tubular Light Emitting Diode (LED) lamps on the productive performance of broilers. The study was carried out in two broiler houses located in Londrina-PR. The lighting system for one of the broiler houses was composed of 52 tubular LED bulbs of $18 \mathrm{~W}$ powers, and the control broiler house consisted of 75 incandescent bulbs with $60 \mathrm{~W}$ powers. This research was divided into two parts; the first phase was evaluated the environmental similarity (dry bulb temperature, air velocity, and illuminance) between the two broiler houses. The second was based on the zootechnical indexes: average body weight, feed intake, feed conversion and mortality. Only the illuminance variable differed statistically. The lighting system based on the use of a tubular LED lamp, with fewer points of illumination and more distant positioning between lamps and lower power installed, did not compromise the zootechnical performance.
\end{abstract}

\section{INTRODUCTION}

The poultry farming contributes positively to the Brazilian agribusiness economy. The poultry farming, according to the Brazilian Association of Animal Proteins (ABPA) (2016), assured to Brazil, in the year of 2015, the position of second largest producer and the world's first exporter. Artificial lighting, characterized by the type of light source, wavelength and intensity, spatial distribution of illuminance and duration of photoperiod (Mendes et al., 2010), acting directly on the behavior, physiology, visual comfort and welfare of the broilers.

The broiler is a photosensitive animal, which can have its behavior and welfare affected by the illumination of the environment (Mendes et al., 2013). The perception of light by this species occurs by direct sensitization of the retina, a specialized region within the eyeball capable of forming images and distinguishing colors, which allows its interaction with the environment, as well as mediating the effects of light on growth and behavior. The retina of the broiler is sensitive to light of wavelength $(\lambda)$, in the approximate interval of $\lambda_{\min }=360 \mathrm{~nm}$ to $\lambda_{\max }=700 \mathrm{~nm}$ (Wilson \& Lindstrom, 2011).

In association, another form of light perception by broilers occurs through the photostimulation of deep regions of the brain, which cover the hypothalamus and the pineal gland (Rathinam \& Kuenzel, 2005), through the red light with $\lambda>700 \mathrm{~nm}$, which crosses the skull (Baxter et al., 2014). Melatonin is a hormone synthesized by the pineal gland, retina and gastrointestinal tract, whose main function is to determine the periodicity of food intake, as well as to induce behaviors associated with the night-day cycle (Huang et al., 2013). In its turn, according to Rozenboim et al. (2012), the hypothalamus acts on physiological processes such as homeostasis and reproduction.

The use of light-emitting diode (LED) lamps stands out in poultry farming because it presents energy saving and provides viability of the breeding process (Santana et al., 2014). Other advantages attributed compared to other lamps (fluorescent and incandescent) include energy efficiency, long shelf life, resistance to humidity, availability of wide wavelengths (light intensities) (Mendes et al., 2013, Cao et al. 2012) and the low cost of dimerization in relation to fluorescent lamps. Researchers have studied the effect of different luminous intensities in poultry, either in egg laying (Nunes et al., 2013, Tsutsui et al., 2012; Borille et al., 2013), such as in meat production

\footnotetext{
${ }^{2}$ Universidade de Campinas/ Campinas - SP, Brasil.

Received in: 6-26-2017

Accepted in: 3-6-2018
} 
(Olanrewaju et al., 2006; Deep et al., 2012; Paixão et al., 2011).

The management of light in the broiler house by imposing different time periods with distinct illuminance is a way of inducing behavior in broilers (Kristensen et al., 2006a), and is the basis of lighting programs proposed by suppliers of poultry genetics. Kristensen et al. (2007) reported that broilers in the first week of life had no preference for any light source. However, at 42 days of age, they preferred light with a spectrum closer to daylight. It is emphasized that the type of light source influenced the behavior of animals more than illuminance.

The artificial lighting used in Brazilian poultry farming is mostly an adaptation of technology available to humans and there is little information on the effects of the use of poultry lamps on the productivity of the broilers. Thus, the objective was to evaluate the thermo-luminous environment and productive performance of broiler lit by LED tubes in commercial conditions.

\section{MATERIAL AND METHODS}

The present study was carried out in two broiler houses located in the region of Londrina / PR, latitude $23^{\circ} 27^{\prime} 32.8^{\prime \prime}$ South, longitude 51 05'30.6" West and altitude $432 \mathrm{~m}$. The local climate, according to the classification of Köppen, is of type (Cfa) subtropical humid, with rains in all the seasons, being able to occur droughts in the winter period. February is the warmest month of the year with average temperature, generally above $25.5^{\circ} \mathrm{C}$ and June is the coldest month, with average temperature below $16.4{ }^{\circ} \mathrm{C}$.

Two lighting systems were compared, one composed of $18 \mathrm{~W}$ tubular LED lamps intended to use in broiler house (Figure 1 - A) and another composed of 60 $\mathrm{W}$ incandescent bulbs (Figure 1 - B), yet available in abundance understock. The two lighting systems (Figure 1 ), through the use of dimmers, were able to supply the broiler house with the illuminance variation of 25 and $5 \mathrm{~lx}$, as recommended by the management of the farm.

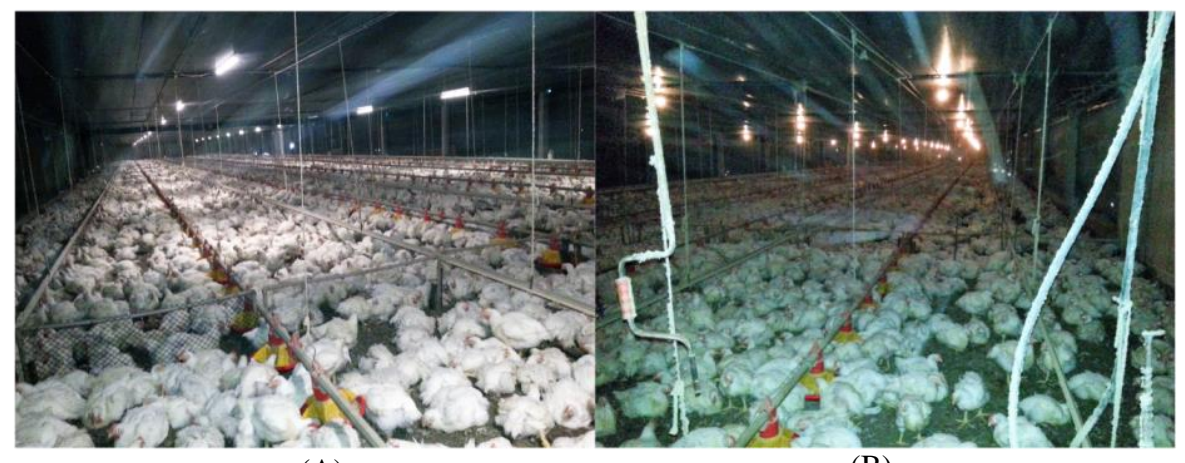

(A)

(B)

FIGURE 1. Broiler house lighting system for raising broilers equipped with (A) tubular LED bulbs and (B) incandescent bulb.

The lighting system of broiler house 1 (Figure 2 - A), is composed of 52 lamps of the model LED Tubular 18 W, supply voltage $220 \mathrm{~V}$, luminous flux $1200 \mathrm{~lm}$ and lifespan of 70,000 hours, dimensions of 1,260 mm in length and $30 \mathrm{~mm}$ in diameter, from the manufacturer EXV Technology, fixed in the broiler house lining at a height of $2.4 \mathrm{~m}$ above the broiler's bed. Broiler house 2 (Figure 2 - B), uses 75 conventional bulb lamps with incandescent filament of $60 \mathrm{~W}$ power, supply voltage of $220 \mathrm{~V}$, luminous flux $715 \mathrm{~lm}$ and lifespan of 1.000 hours, standard thread E27, of the manufacturer Osram, fixed in the ceiling of the broiler house at a distance of $2.2 \mathrm{~m}$ above the bed. 

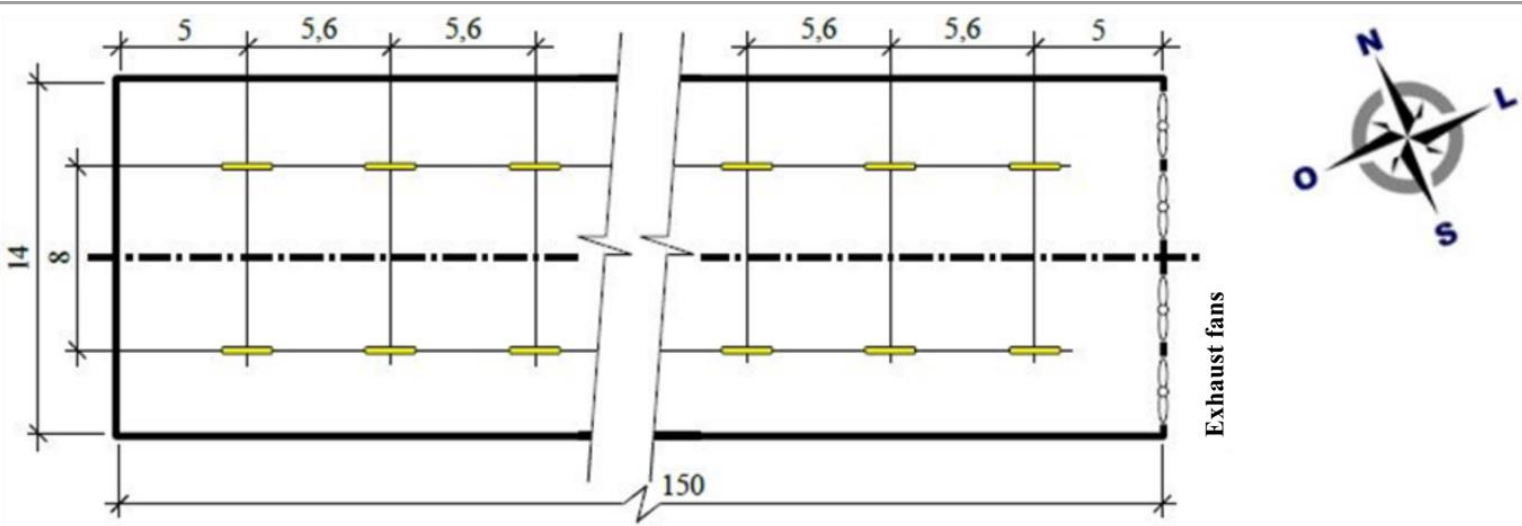

(A)

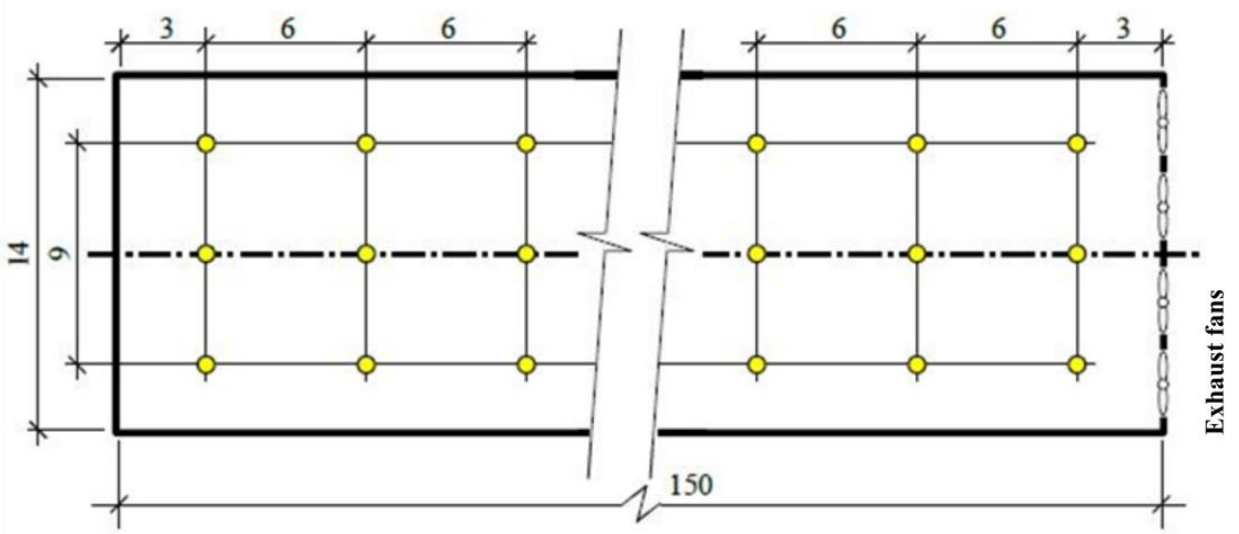

(B)

Dimensions [m]

FIGURE 2. Layout of 52 tubular LED lights in the broiler house 1 (A) and 75 conventional incandescent light bulbs in broiler house 2 (B).

The lighting program, composed of two phases, was identical for both broiler houses. The first phase consisted of a photoperiod of 23 light hours, with illuminance of $25 \mathrm{~lx}$, at the height of the broilers, during the first seven days of life of the lot. The second phase ran from the eighth day of age until the animals were collected for slaughter, with photoperiod of 18 hours and illuminance of $5 \mathrm{~lx}$.

In each broiler house, 30,000 broilers of Cobb lineage (male and female) from a same commercial hatchery were housed. In both broiler houses, the density of 14 broilers $\mathrm{m}^{-2}$ was used, as well as the same feeding / nutritional management. Each facility contained four feeder lines, five lines of nipple type drinking fountains, of identical configuration, in automated distribution systems. The management of the animals was performed by the same employee.

The broiler houses of this study have the same construction pattern (masonry structures in the pillars and beams, metal structure for roof support, concrete floor and masonry wall of $0.4 \mathrm{~m}$ high) and ventilation control systems (11 exhaust fans of $1 \mathrm{CV}$ of power, supply voltage of $220 \mathrm{Vac}$, of the manufacturer Plasson, model without cone, with estimated flow of $33,100 \mathrm{~m}^{3} \mathrm{~h}^{-1}$, to $20 \mathrm{~Pa}$, differing only in the lighting system. These installations are of the Dark house type, with dimensions of $150 \mathrm{~m}$ in length, $14 \mathrm{~m}$ wide and $2.6 \mathrm{~m}$ high, operate with ventilation in the negative pressure system. The roof slope of $11^{\circ}$ is composed of $6 \mathrm{~mm}$ thick fiber cement tiles, the black polyethylene curtain lining, lateral insulation of black polyethylene curtain on the inner face and silver on the outer face.

The cooling system installed at $0.4 \mathrm{~m}$ above the floor is composed of two identical rectangular areas $(20 \mathrm{~m}$ long and $2.10 \mathrm{~m}$ high), located on two side walls at the opposite ends of the air outlet (exhaust fans). This system consists of a wall of hollow bricks and four mist lines, 0.5 $\mathrm{m}$ apart. Each line has 15 spray nozzles distributed evenly $(1.4 \mathrm{~m})$ along the entire length of the system. The ventilation system is composed of air intakes in the side walls at the beginning of the broiler house and a set of eleven exhaust fans at the end. The cooling, when necessary, was done by the use of water sprinklers, positioned at the height of the lining, respecting the same layout in both broiler houses. The high pressure nebulization system for the interior of the broiler house consists of 19 lines, the first 10 containing 11 nozzles, and the other lines with 10 nozzles, evenly distributed. These 19 lines are arranged perpendicularly to the length of the broiler house, and distant each other of $5.7 \mathrm{~m}$, the first line being $25 \mathrm{~m}$ away from the wall opposite the exhaust fans. The sheds also had an independent sprinkler system, located on the perforated ceramic bricks of the air intake, emulating an adiabatic cooler.

The control of the ventilation systems and temperature regulation is done through a dedicated equipment Fancontrol brand; model CC3.This controller basically performs two functions: control the minimum ventilation and the temperature. The minimum timecontrolled ventilation system is carried out by the set of 2 
exhaust fans, responsible for the renewal of the air through a variable percentage of time that remains connected within a range of 4 minutes. This percentage is raised weekly, following the age of the broilers. The temperature control, respectively, activates different groups of exhaust fans, followed by cooling, and finally the last, the misting system, according to the need. The temperature recommended by the producer, varies weekly being registered in the controller, starting with $32^{\circ} \mathrm{C}$ in the first week, and ending with $21{ }^{\circ} \mathrm{C}$ of the last week of the broilers accommodation.

\section{Environmental variables}

In order to verify the influence of the environmental factors inside the broiler houses, the values of the dry bulb temperature $\left({ }^{\circ} \mathrm{C}\right)$, air velocity $\left(\mathrm{m} \mathrm{s}^{-1}\right)$ and illuminance $(\mathrm{lx})$ were measured. The dry bulb temperature and air velocity were obtained by means of a hot wire thermometer (accuracy of $0.1{ }^{\circ} \mathrm{C}$ and $0.015 \mathrm{~m} \mathrm{~s}^{-1}$, respectively). The luminous intensity was measured by means of a luxmeter with an accuracy of $\pm 3 \%$.

The records were made at a $0.3 \mathrm{~m}$ elevation of the broiler's bed (Pereira et al., 2012), and in positions that guarantee the representativeness of the different microclimates inside the tunnel-type broiler houses (Figure 3 ). Thus, there are three distinct regions: (A) initial region, near the air inlet; (B) central position of the broiler house and $(\mathrm{C})$ final region near the exhaust fans. The collection occurred at 42 days of age, at the same time of the day (morning) and at the summer season.

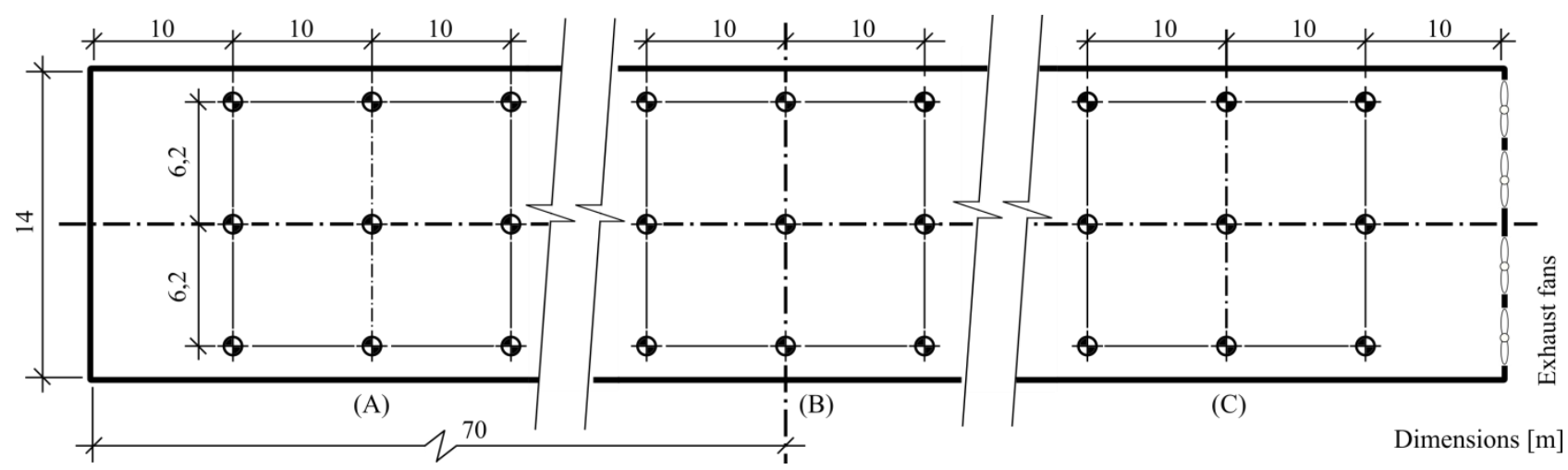

FIGURE 3. Position and sequence of data collection of environmental variables in the broiler houses.

\section{Performance}

To evaluate the performance, the following parameters were used: (1) Average live weight (AW), obtained by weighing the broilers in a random way, in three regions of the broiler house, with $3 \%$ of the total sample at 42 days of age; The feed conversion (FC), defined as a relation between the average feed intake of the poultry batch (FI) divided by the respective average weight gain of the same batch in the 42 day period, (3) the average feed intake of the batch of broilers (AFI); (4) mortality of broilers (M).

\section{Data analysis}

The design used for the environmental variables and the zootechnical performance was completely randomized to the lighting factor, with three replicates, the repetition being composed of nine equidistant averages within the broiler house for the environmental variables, and three production batches for performance. The data were submitted to the analysis of variance using the program Assistat version 7.6 and submitted to the F test. The comparison between averages for the environmental variables was performed by the Tukey test at 5\% probability. For the zootechnical indexes, the means were compared by the Student $t$ test at $5 \%$ of probability.

\section{RESULTS AND DISCUSSION}

\section{Environmental Characteristics}

The descriptive statistical analysis together with the mean values of the environmental variables for the incandescent bulb and tubular LED broiler houses are listed in Table 1.

TABLE 1. Synthesis of the descriptive statistics of the environmental variables of broiler houses with different lighting systems.

\begin{tabular}{|c|c|c|c|}
\hline Type de lighting & $\mathrm{t}_{\mathrm{db}}\left({ }^{\circ} \mathrm{C}\right)$ & Vair $\left(\mathrm{ms}^{-1}\right)$ & Illuminance $(\mathrm{lx})$ \\
\hline Incandescent Bulb & $23.38 \mathrm{a}$ & $0.96 \mathrm{a}$ & $2.45 \mathrm{a}$ \\
\hline Tubular LED & $23.46 \mathrm{a}$ & $0.89 \mathrm{a}$ & $1.00 \mathrm{~b}$ \\
\hline Standard deviation & 1.12 & 0.09 & 1.73 \\
\hline $\mathrm{CV} \%$ & 5.37 & 9.64 & 0.84 \\
\hline $\mathrm{P}$-value & 0.72 & 0.23 & 0.05 \\
\hline
\end{tabular}

The averages followed by the same letter do not differ statistically from each other by the Tukey test at the $5 \%$ probability level. $t_{d b}=d_{r y}$ bulb temperature; Vair $=$ velocity of the air $; \mathrm{CV} \%=$ coefficient of variation. 
The mean temperature of air inside the broiler house with illumination of tubular LED lamps was 23.46 ${ }^{\circ} \mathrm{C}$, and for the broiler house with illumination of $23.38^{\circ} \mathrm{C}$ with incandescent lamps, there was no statistical difference between the systems $(\mathrm{P}>0.05)$. The temperature variation in both broiler houses was within the breeding interval, according to recommendations of Cobb (2014) genetics provider. Broilers rely on adequate internal microclimate to express their genetic potential for production. Despite the recent increase in the number of acclimatized broiler facilities in Brazil (Curi et al., 2017), the challenge of providing environmental conditions within the comfort zone for animals is still present, especially for tropical and subtropical countries (Bustamante et al., 2013).

The mean air velocity for the broiler house with LED tubular lighting was $0.89 \mathrm{~m} \mathrm{~s}^{-1}$, and for the lighting system with incandescent lamps $0.96 \mathrm{~m} \mathrm{~s}^{-1}$. These data are below the one recommended by Yahav et al. (2001), which determines ideal values in the range of 1.5 to $2 \mathrm{~m} \mathrm{~s}^{-1}$, indicating management potential of this variable.

Illuminance was the only environmental variable that obtained a significant difference between the lighting systems $(\mathrm{P}<0.05)$, and the highest average $(2.45 \mathrm{~lx})$ observed in the treatment with incandescent bulb lamps. This difference is due to the smaller number of tubular LED lamps installed, imposing a greater spacing between lamps. According to Pereira et al. (2012), the spatial distribution of illuminance is influenced by the quantity and geometry of the lamp, but also by its position inside the broiler house.
Similar to Pereira et al. (2012), three factors influenced the spatial distribution of illuminance: (1) two types of lamps with distinct geometries, one of tubular LED applied to broiler house 1, and another one of incandescent bulb present in broiler house 2; (2) different amounts of light points, with 52 lamps for the broiler house 1 and 75 lamps for the broiler house 2; (3) and different positioning of the lamps for the two broiler houses, as can be observed in Fig. 2.

In the study by Deep et al. (2012) were considered different values of characteristic illuminance $(1,10,20$ and $40 \mathrm{~lx}$ ), covering a maximum amplitude between the lowest and highest illuminance values of the order of 40 times. On the other hand, in this study the mean illuminance values for the two broiler houses presented amplitude of the order of 2.5 times.

For Blatchford et al. (2012) the duration of the photoperiod and the intensity of the illuminance are relevant aspects in the environmental illumination for broiler breeding, as they influence the circadian cycle of the broilers. However, the light and dark contrast, i.e. the difference between daytime (photoperiod) illuminance and nocturnal illuminance (escotoperiod) is more influential in the behavior and welfare of broilers than the duration of the photoperiod in the performance.

The descriptive statistical analysis of the zootechnical indexes for the two types of lighting systems is presented in Table 2 .

TABLE 2. Synthesis of the descriptive statistics of the zootechnical indexes of broiler reared in broiler houses with different lighting systems.

\begin{tabular}{lcccc}
\hline Illumination & MW $(\mathrm{kg})$ & FI $(\mathrm{kg})$ & FC $(\mathrm{kg} / \mathrm{kg})$ & $\mathrm{M}(\%)$ \\
\hline Incandescent Bulb & $2.773 \mathrm{a}$ & $4.901 \mathrm{a}$ & $1.787 \mathrm{a}$ & $5.30 \mathrm{a}$ \\
LED tubular & $2.855 \mathrm{a}$ & $4.859 \mathrm{a}$ & $1.723 \mathrm{a}$ & $5.34 \mathrm{a}$ \\
\hline Standard deviation & 0.16 & 0.24 & 0.05 & 1.44 \\
CV \% & 6.13 & 4.99 & 2.85 & 27.07 \\
P-value & 0.589 & 0.859 & 0.159 & 0.982 \\
\hline
\end{tabular}

The averages followed by the same letter do not differ statistically from each other by $t$ Test at the 5\% probability level. MW = mean weight; $\mathrm{FI}=$ feed intake $\mathrm{FC}=$ feed conversion; $\mathrm{M}=$ mortality. $\mathrm{CV} \%=$ coefficient of variation.

Observing Table 2, the results showed no significant differentiation for zootechnical indexes. Thus, the tubular LED illumination system did not alter the zootechnical performance of the animals when compared to the incandescent bulb lighting system.

The results observed in Table 2 are in agreement with those obtained by Deep et al. (2012) and Olanrewaju et al. (2014) because the similarity of the illuminance values of both passengers was not significant to influence the zootechnical parameters studied. Deep et al. (2010) did not identify a statistical difference for the zootechnical indexes when they studied the influence of the illuminance variation on the productive, processing and welfare characteristics of different levels of luminance (1, 10, 20 and $40 \mathrm{~lx}$ ) in closed broiler houses.

Paixão et al. (2011) verified that the white LED lamp has the same effect of the fluorescent lamp on the productive performance of broilers (feed intake, live weight, feed conversion), making it viable due to the saving of electric energy. For Santana et al. (2014), LED illumination in different colors and illuminance, when compared to fluorescent light, did not affect growth performance parameters of broilers (weight gain, feed intake and feed conversion), carcass and cut trim (chest, thigh + drumstick). In this way, LED lighting provides greater energy efficiency, increasing the sustainability of the system, and is therefore suitable for the production of broilers.

The influence of different values of illuminance on growth performance of broiler and carcass characteristics was studied by Olanrewaju et al. (2014) In the study of two lines submitted to illuminance of $25,10,5,2.5$ and 0.2 $1 \mathrm{x}$, the authors concluded that there was no impairment to welfare and productive parameters due to the different values of illuminance evaluated. In addition, it was suggested that the use of low values of illuminance could increase feed conversion, without damaging the welfare of the broilers, besides providing lower energy consumption.

In an experiment performed by Kristensen et al. (2006b), we evaluated the locomotive health and productive parameters of broilers raised in an environment illuminated by two distinct light sources, the Osram biolux 
lamp and the Osram warm-white lamp, with two different illuminance values 2.5 and 50 lux. The results showed that there was a correlation between the weight of the broiler and locomotive performance, but no influence of the ambient light on body weight, feed intake and mortality was observed. They concluded that the two sources of light at different lighting levels did not significantly affect locomotive health and production parameters.

The lack of significative influence in the productive results, due to the variation of the illuminance intensity, was also observed by Newberry et al. (1988), who had illuminance values of $180 \mathrm{~lx}$ and $6 \mathrm{~lx}$. The behavior of the broiler that was expressed by its level of activity was significantly influenced by the illuminance value of $180 \mathrm{~lx}$, but the feed intake and water did not. The results regarding body weight, feed and water intake and feed conversion were not altered by different illuminances.

Skoglund \& Palmer (1962), in order to establish a minimum illuminance limit value at the height of the feeders for which the highest weight gain would be obtained for broilers, used illuminance values of $5.4 \mathrm{~lx}$, $21.51 x, 53.81 x, 107.61 x$ and $1291.61 x$. In this study, the illuminance values, $21.5 \mathrm{~lx}$ and $53.8 \mathrm{~lx}$, presented a significant statistical difference for weight gain, when compared to the illuminance of 1291.6 lx. However, for the lowest value illuminance $(5.4 \mathrm{~lx})$, there was no significant difference when compared to the illuminance values $21.5 \mathrm{~lx}$ and $53.8 \mathrm{~lx}$. Thus, the authors concluded that the values of illuminance lower than $107.6 \mathrm{~lx}$ provided an increase in the animals' weight. In addition, it was verified that values of illuminance lower than $5.4 \mathrm{~lx}$, could contribute even more to the elevation of the broilers' weight.

Deep et al. (2012) studied the effect of different illuminance indexes $(1,10,20$, and $40 \mathrm{~lx})$ on the behavior and daytime rhythm of broilers, measured the level of melatonin, which is the hormone responsible for night and day cycle synchronization of the broilers. Melatonin levels and food and water intake behavior were not influenced by the different values of illuminance studied. The presence of melatonin in the broilers' blood followed the pattern of abundance in the dark period (11:00 p.m. to 06:00 a.m.) and shortage in the photoperiod. In this study it was observed that the illuminance lower than $1 \mathrm{~lx}$ induced a longer rest period in the broilers, besides reducing the expression of behaviors that could indicate comfort and welfare.

\section{CONCLUSIONS}

Environmental similarity was observed among broiler houses for the variables temperature and air velocity. However, the illuminance was a differentiation variable between the broiler houses. The illuminance in the broiler house in which the tubular LED lamps were installed was statistically lower when compared to the broiler house with incandescent bulbs, due to the smaller number of lamps and the greater distance among them. The accommodation of broiler with a tubular LED lighting system did not change the animal performance when compared to the incandescent bulb lighting system

\section{REFERENCES}

ABPA - Associação Brasileira de Proteína Animal (2016) In: Relatório Anual. Available in: http://abpa-br.com.br. Accessed: Aug 12, 2016.

Baxter M, Joseph N, Osborne VR, Bedecarrats GY (2014) Red light is necessary to activate the reproductive axis in broilers independently of the retina of the eye. Poultry Science 93:1289-1297.

Blatchford RA, Archer GS, Mench JA (2012) Contrast in light intensity, rather than day length, influences the behavior and health of broiler. Poultry Science 91:17681774 .

Borille R, Garcia RG, Royer AFB, Santana MR, Colet S, Nääs IA, Caldara FR (2013) The use of light emitting diodes (LED) in commercial layer production. Brazilian Journal of Poultry Science 15(2):135-140.

Bustamante E, García-Diego FJ, Calvet S, Estellés F, Beltrán P, Hospitaler A, Torres AG (2013) Exploring ventilation efficiency in poultry buildings: The validation of computational fluid dynamics (CFD) in a crossmechanically ventilated broiler farm. Energies 6:26052623.

Cao J, Wang Z, Dong Y, Zhang Z, Li J, Li F, Chen Y (2012) Effect of combinations of monochromatic lights on growth and productive performance of broilers. Poultry Science 91(12):3013-3018.

Cobb-Vantress Inc (2014) Manual de Manejo de Frangos de corte. Available in: http://www.cobbvantress.com/languages/guidefiles/b5043b0f-792a-448eb4a1-4aff9a30e9eb_pt.pdf . Accessed: Jul 29, 2016.

Curi TMRC, Moura DJ, Massari JM, Mesquita M, Pereira DF (2017) Computational Fluid Dynamics (Cfd) application for ventilation studies in aviaries. Engenharia Agrícola 37(1):1-12.

Deep A, Schwean-Lardner K, Crowe TG, Fancher BI, Classen, HL (2010) Effect of light intensity on broiler production, processing characteristics, and welfare. Poultry Science 89:2326-2333.

Deep A, Schwean-Lardner K, Crowe TG, Fancher BI, Classen, HL (2012) Effect of light intensity on broiler behavior and diurnal rhythms. Applied Animal Behaviour Science 136:50-56.

Huang H, Wang Z, Weng SJ (2013) Neuromodulatory role of melatonin in retinal information processing. Progress in Retinal and Eye Research 32:64-87.

Kristensen HH, Aerts JM, Leroy T, Wathes CM, Berckmans D (2006a) Modelling the dynamic activity of Broiler in response to step-wise changes in light intensity. Applied Animal Behavior Science 101:125-143. 
Kristensen HH, Perry GC, Prescott NB, Ladewig J, Ersbøll AK, Overvad KC, Wathes CM (2006b) Leg health and performance of broiler reared in different light environments. British Poultry Science 47:257-263.

Kristensen HH, Prescott NB, Perry GC, Ladewig J, Ersbøll. AK, Overvad KC, Wathes CM (2007) The behavior of broiler in different light sources and illuminances. Applied Animal Behavior Science 103:7589.

Mendes AS, Reffati R, Restelatto R, Paixão JS (2010)

Visão e iluminação na avicultura moderna. Revista Brasileira Agrociência 16(1-4):5-13.

Mendes AS, Paixão SJ, Restelatto R, Morello GM, Moura DJ, Possenti JC (2013) Performance and preference of broiler exposed to different lighting sources. The Journal of Applied Poultry Research 22(1):62-70.

Newberry RC, Hunt JR, Gardiner EE (1988) Influence of Light Intensity on Behavior and performance of broiler. Poultry Science 89(2):1020-1025.

Nunes KC, Garcia RG, Borille R, Nääs IA, Santana MR (2013) Led como fonte de luz na avicultura de postura. Enciclopédia Biosfera 9(17):1775-1782.

Olanrewaju HA, Thaxton JP, Dozier III WA, Purswell J, Roush WB, Branton SL (2006) A Review of Lighting Programs for Broiler Production. International Journal of Poultry Science 5(4):301-308.

Olanrewaju HA, Miller WW, Maslin WR, Collier SD, Purswell J, Branton SL (2014) Effects of strain and light intensity on growth performance and carcasscharacteristics of broilers grown to heavy weights. Poultry Science 93:1890-1899.

Paixão SJ, Mendes AS, Restelatto R, Marostega J, Souza C, Posssenti JC (2011) Desempenho produtivo de frangos de corte criados com dois tipos de lâmpadas. In: I Simpósio de Ciências Florestais e Biológicas, Campus Dois Vizinhos, VII Congresso de ciência e tecnologia da UTFPR.
Pereira PA, Yanagi Jr T, Da Silva JP, De Lima RR, Campos AT, Abreu LHP (2012) Technical evaluation of artificial lighting systems for Aviaries. Engenharia Agrícola 32(6):1011-1024.

Rathinam T, Kuenzel WJ (2005) Attenuation of gonadal response to photostimulation following ablation of neurons in the lateral septal organ of chicks. Brain Research Bulletin 64:455-461.

Rozenboim I, Mobarkey N, Avital-Cohen N, KashashHanin Y, Heiblum R, Chaiseha Y, El Halawani ME (2012) Photostimulation effects on reproductive activities of domestic birds. In: XXIV World's Poultry Congress, Salvador-Brazil, Poultry Welfare and Environment.

Santana MR, Garcia RG, Nääs IA, Paz ICLA, Caldara FR, Barreto B (2014) Light emitting diode (LED) use in artificial ligthing for Broiler broiler production. Engenharia Agrícola 34(3):422-427.

Skoglund WC, Palmer DH (1962) Light Intensity Studies With Broilers. Poultry Science 41:1839-1842.

Tsutsui K, Ubuka T, Bentley GE, Krieqsfeld LJ (2012) Gonadrotopininhibitory hormone $(\mathrm{GnRH})$ : discovery, progress and prospect. General and Comparative Endocrinology 177(3):305-314.

Yahav S, Straschnow A, Vax E, Razpakoviski V, Shinder D (2001) Air velocity alters broiler performance under harsh environmental conditions. Poultry Science 80:724726.

Wilson M, Lindstrom SH (2011) What the bird's brain tells the bird's eye: The function of descending input to the avian retina? Visual Neuroscience 28(4):337-350. 